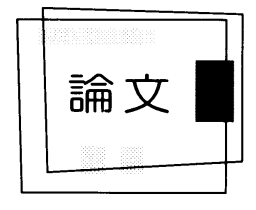

\title{
環境に優しく低コストの舶用燃料油の設計と 性能評価一廃プラスチック油(WPD)利用一*
}

\author{
Vu Phong Hai** 西田 修身** 藤田 浩嗣** \\ 原野 亘 $* *$ 豊島 紀彦*** 射手矢 政美 $* * * *$
}

Development and Evaluation of Marine Fuel Oil for Clean Environment and Reduction of Running-Cost

- Utilization of Waste Plastics(WPD) -

Vu Phong Hai, Osami Nishida, Hirotsugu Fujita, Wataru Harano, Norihiko Toyoshima, Masami Iteya

In order to revitalize sea transportation it is essential to be capable of using low-cost, low-quality fuel oil with simplified fuel systems, the emissions of which must be environmental-friendly. The authors of this paper have developed the blended oil of Marine Heavy Fuel Oil (C-Oil) and pyrolytic oil made of household and industrial waste plastics (hereafter called Waste Plastic Disposal or WPD) and applied it to diesel engines. The experiment on the engine with non-preheated blended oil has shown the stable operation of the engine. This would lead to the significant reduction of heating cost. Furthermore, the emission of soluble organic fraction (SOF) also decreases. This paper discribes the effects of sulfur content on the engine performance and emission. However, NOx emission slightly increases so that the emulsified fuel oil has been made with the aid of capsule-typed additives. The experimental emulsion fuel oil (Emulsion F.O) containing 10\%(v) water and $0.3 \%$ (v) additives indicates stability and helps to reduce NOx emission almost by half.

\section{1. まえがき}

海運界活性化のためには, より安価な燃料油を 簡易なシステムのもとで使用可能とすることであ る。同時に環境に優しい排ガス特性を示す燃料油 でなければいけない，筆者らは家庭及び産業廃棄 物であるプラスチックから高効率(約90\%)で回収し た廃プラスチック油(今後, 廃プラスチック油はWPD とする $)^{(1)}$ とC重油をブレンドした新種油を開発し， 実機に使用したところ, 非加熱の状態で運転可能 を示した ${ }^{(2) ~(7)}$. その結果, 燃料油加熱コストを大 幅に削減でき, 安定な運転が可能であったととも に微粒子特にSOFの低減を計ることができた。し かしながら，NOxについては若干の増加が認めら れたため, 特殊なカプセル式乳化剂による水添加

$*$ 原稿受付 平成 12 年 10 月 13 日

**正会員 神戸商船大学（神戸市東灘区深江南町 5-1-1)

$* * *$ 日邦産業 $\mathrm{K} . \mathrm{K}$

$* * * *$ WOS-21 CO.,Ltd
エマルジョン燃料油を試作した，水と油の混合に あたり，カプセル式乳化剤による乳化燃料油を作 成した結果，よい安定性が得られ，実機試験の結 果で, NOx排出量を約半減することができた.

\section{2. 供試燃料油の性状}

\section{1 C重油とWPDの混合油の特性 本実験} に使用のC重油の性状值，WPDの性状分析值及び 供試燃料油の構成内容をそれぞれ表 $1 ， 2 ， 3$ に示 した。C重油中の硫黄分及び残留炭素分は2.56, $12.3 \%(\mathrm{~m} / \mathrm{m})$ である。また, WPD 中の成分の約六 十数\%はスチレンモノマーである，両油の比較にお いて，密度に大きな差がないが，動粘度には大き な差異がある。C重油の動粘度は $50{ }^{\circ} \mathrm{C}$ で $177 \mathrm{cSt}$, 密度は $0.982 \mathrm{~g} / \mathrm{cm}^{3}$, 硫黄含有率は $2.56 \%(\mathrm{~m} / \mathrm{m})$ で ある。WPDの密度はC 重油並みの $0.939 \mathrm{~g} / \mathrm{cm}^{3}$ で あるが，動粘度は約 $1.2 \mathrm{cSt}\left(30^{\circ} \mathrm{C}\right)$ で極めて低い，C 重油にWPDを $10 ， 20 ， 30 \%(\mathrm{v})$ 添加した場合の密 
度，粘度， CCAI值(着火性指標)及び硫黄分変化を 図1に示した。罒より，WPDの添加率増加に伴っ て，密度，動粘度及び硫黄分が小さくなる。特に 動粘度は添加率 $20 \%(\mathrm{v})$ で急激に低下し, 約 $1 / 9$ に なる。しかしWPDの割合を増すほど，CCAI值は 増し, セタン価が減少する。 CCAI值以外の性状は 機関使用燃料油には良い傾向である。さらに蒸留 特性を把握するために，示差熱分析計 (DTG$50 / 50 \mathrm{H}) に て$, 種々供試油の蒸留曲線を示したの が図 2 である。図より全試料とも $500^{\circ} \mathrm{C}$ 付近で $90 \%$

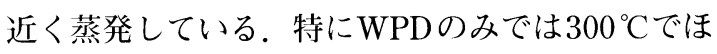
ぼ蒸発が完了する。

2.2 C重油とWPDと水のエマルジョン燃料の 性能試験結果 NOx排出を抑制するために, C 重油とWPD 90:10\%(v)の混合油をべースとし，べ 一ス油に水を $10,20 \%(\mathrm{v})$ 混入した.安定なエマルジ ヨンを得るために, 乳化剂(商品名:WOS-21)を $0.3 \%$ (v)（ベース油に水を混合した混合油に対する 体積割合)添加した。この供試燃料油の特性と, 実 機での機関性能及び排気ガス特性の検討を行った。

\section{表1 C 重油成分分析表}

\begin{tabular}{|c|c|c|}
\hline \multicolumn{3}{|c|}{ JOMO C.OII No. 30E } \\
\hline Item & Unit & Value \\
\hline Density $\left(15^{\circ} \mathrm{C}\right)$ & $\mathrm{g} / \mathrm{cm}^{3}$ & 0.982 \\
\hline Reaction degree & & Neutral \\
\hline Flash point & ${ }^{\circ} \mathrm{C}$ & 74.0 \\
\hline Kinematic viscosity $\left(50^{\circ} \mathrm{C}\right)$ & $\mathrm{m} \mathrm{m}^{2} / \mathrm{s}(\mathrm{cSt})$ & 177.0 \\
\hline Pour point & ${ }^{\circ} \mathrm{C}$ & -10.0 \\
\hline Carbon residue & $\%(\mathrm{~m} / \mathrm{m})$ & 12.3 \\
\hline Sulfur & $\%(\mathrm{~m} / \mathrm{m})$ & 2.56 \\
\hline Water & $\%(\mathrm{~m} / \mathrm{m})$ & 0.00 \\
\hline Ash & $\%(\mathrm{~m} / \mathrm{m})$ & 0.020 \\
\hline Nitrogen & $\%(\mathrm{~m} / \mathrm{m})$ & 0.25 \\
\hline Gross Calorific Value & $\mathrm{MJ} / \mathrm{kg}(\mathrm{kcal} / \mathrm{kg})$ & $42.780(10,220)$ \\
\hline Vanadium & $\mathrm{m} \mathrm{g} / \mathrm{kg}$ & 58 \\
\hline Aluminum & $\mathbf{m ~ g / k g}$ & 4 \\
\hline Magnesium & $\mathbf{m} \mathbf{g} / \mathbf{k g}$ & 2 \\
\hline Silica & $\mathbf{m} \mathbf{g} / \mathbf{k g}$ & 13 \\
\hline
\end{tabular}

表2 廃プラスチック熱分解油（WPD） 成分分析表

\begin{tabular}{|c|c|c|c|}
\hline \multicolumn{2}{|c|}{$\begin{array}{r}\text { Item } \\
\end{array}$} & Unit & Value \\
\hline \multicolumn{2}{|c|}{ Density $\left(15^{\circ} \mathrm{C}\right)$} & $\mathrm{g} / \mathrm{cm}^{3}$ & 0.939 \\
\hline \multicolumn{2}{|c|}{ Kinematic viscosity $\left(30^{\circ} \mathrm{C}\right)$} & $\mathrm{m} \mathrm{m}^{2} / \mathrm{s}$ (cSt) & 1.189 \\
\hline \multirow{2}{*}{\multicolumn{2}{|c|}{$\begin{array}{l}\text { Gross calorific value } \\
\text { Flash point }\end{array}$}} & $\mathbf{M J} / \mathbf{K g}$ & 44.99 \\
\hline & & ${ }^{\circ} \mathrm{C}$ & 30.5 \\
\hline \multirow{7}{*}{ Components } & Styrene monomer & $\%(v)$ & 63.9 \\
\hline & Styrene dimer & $\%(v)$ & 11.5 \\
\hline & Styrene trimer & $\%(v)$ & 5.7 \\
\hline & Toluene & $\%(v)$ & 2.2 \\
\hline & Ethyl benzen & $\%(v)$ & 1.4 \\
\hline & $\alpha$ - methyl styrene & $\%(v)$ & 2.2 \\
\hline & Others & $\%(v)$ & 13.1 \\
\hline
\end{tabular}

本実験に使用した乳化添加剤は重質油中に水粒 子を分散させウォーター・イン・オイル型エマル ジョンを形成するための乳化牏であって, 苛性ソ 一ダ $25 \%(\mathrm{v})$ と塩化カルシウム $25 \%(\mathrm{v})$ と水 $50 \%(\mathrm{v})$ と を主成分とする重質油処理用乳化剂である. 水と 重質油に乳化剤を加えて混合することによって得 られるこのカプセル燃料は, 下記のような特徵を 有するエマルジョン化した新燃料となった。

\section{表3 供試燃料油の構成内容（体積割合）}

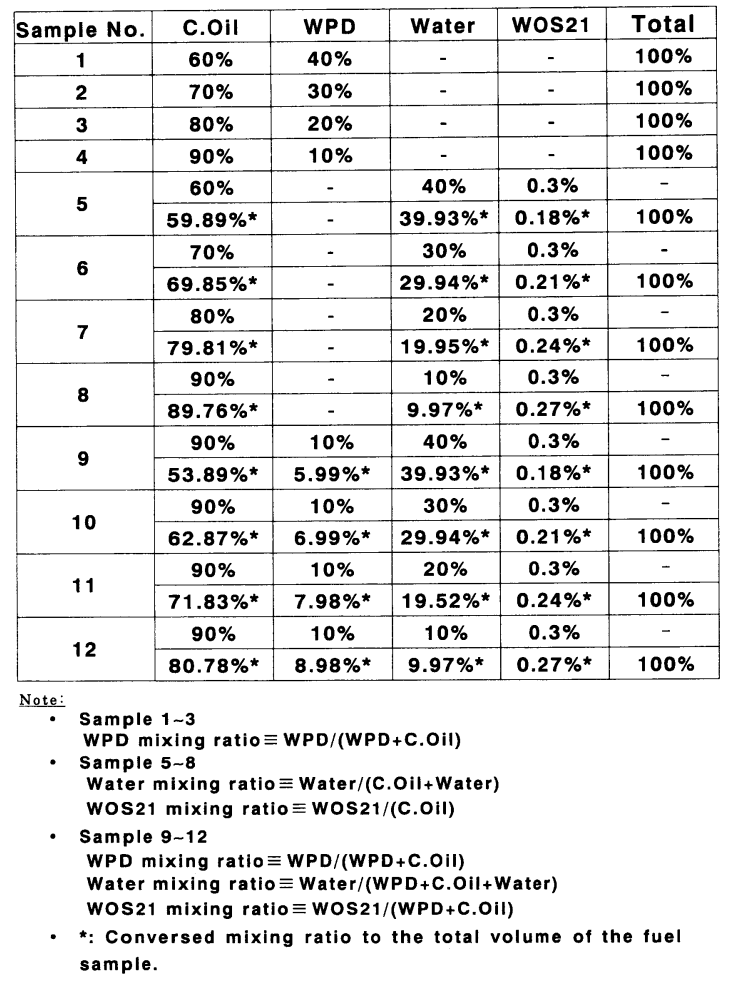

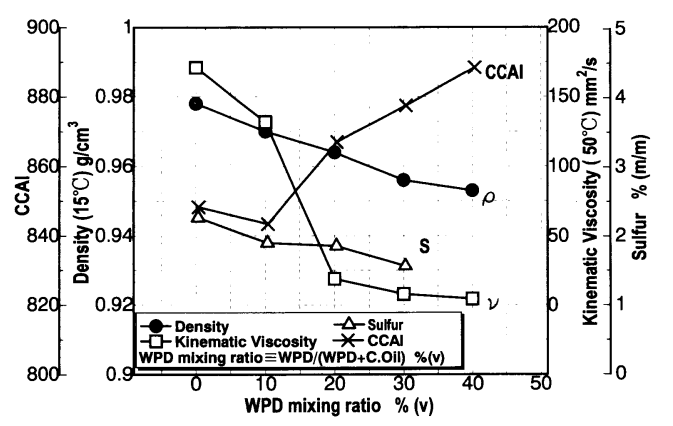

図1 供試燃料油のWPD添加による 特性の変化 
(1)乳化剤によりカプセル化された重質油と水は, 強力な分子間相互作用により分離しない.

(2)油滴の中に水滴が閉じ込められているが，保 管・運用などは重質油と同様な取り扱いである。

(3) 全体量の $60 \%$ 程度まで水を混入し, カプセル 化できる。

図3は実際のカプセル燃料(水\%(v)混入)を200倍 拡大した写真である。もっとも大きく見える 3 油滴 は焦点に合わし撮影し, 他の油滴は被写体深度の 差により小さく見える。これらの性能試験結果は 以下の通りであった。

(a) 24 時間保管したカプセル燃料を $80{ }^{\circ} \mathrm{Cにし，}$ 遠心分離器 (相対遠心力 $600 \mathrm{G}$ で 20 分間回転) にかけたが，分離はなかった。

(b) 7 日間保管したカプセル燃料を $80^{\circ} \mathrm{Cにし,}$ 心分離器(相対遠心力 $600 \mathrm{G}$ で 20 分間回転)に かけたが, 分離はなかった。

図4にエマルジョン燃料油の動粘度と密度の变化 を示した，図より，水添加率が 10\%から40\%に増加

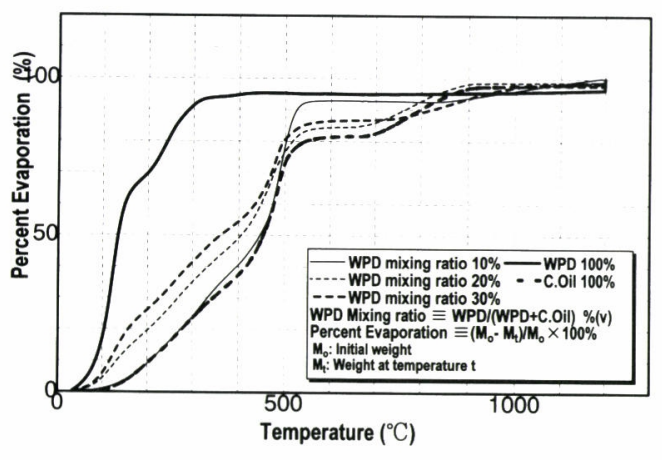

図2 供試燃料油の蒸留曲線

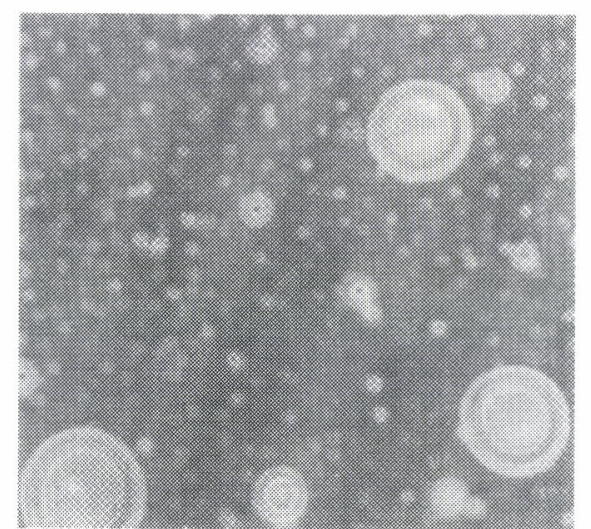

図3 エマルジョン燃料油の顕微鏡写真

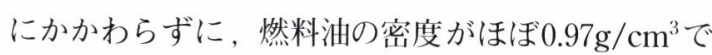
一定である。しかしながら，エマルジョン燃料油 の動粘度は $167 \mathrm{cSt}$ から 454cStに急激に増加し， WPD と混合したエマルジョン燃料油の動粘度は $167 \mathrm{cSt}$ から $232 \mathrm{cSt} に$ 漸増する。明らかになったこ とは, WPD添加により，WPD添加したC重油エマ ルジョン燃料の動粘度は C 重油エマルジョン燃料 の動粘度よりほぼ100～300cSt低い。

図5は供試燃料油の蒸留曲線を示す。図より水 添加が増すほど燃料油の蒸留速度が増加する傾向 が見られる。さらに，C重油及びWPD 10\%(v) C 重 油 $90 \%(v)$ 混合油と比べ, WPDエマルジョン燃料油 の蒸留速度は速くなる。

\section{3. 実験機関及び方法}

表4には実験に使用した機関の細目を示した.使 用した機関は単気管横型水冷式4ストロークディー ゼル機関(NF19SK)であり，定格出力は $2200 \mathrm{rpm}$, $12 \mathrm{~kW}$ である。罒6は機関性能及び排ガス測定系の

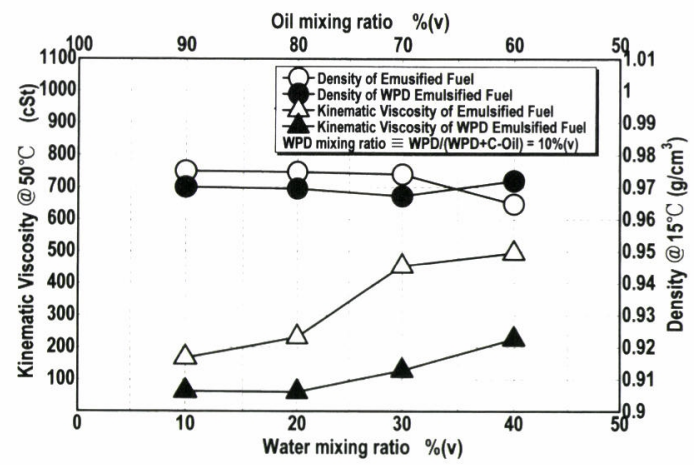

図4 供試燃料油の水添加による特性の変化

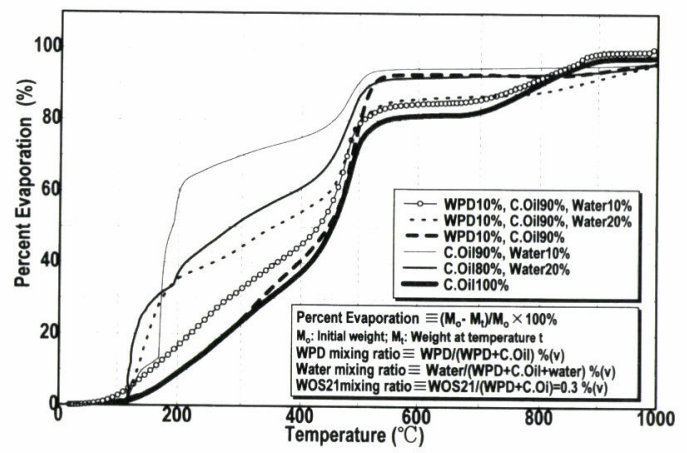

図5 供試燃料油の水添加による蒸留特性の変化 
概略を示す。

実験は機関回転数 $2200(\mathrm{rpm})$ 及び 機関負荷 $75(\%)$ 一定で運転をし，各項目について測定を行った。 また，混合燃料油の均一化を図るために燃料タン クに覧拌機を取りつけ，実験開始から終了時まで 攪找を行った。化学発光方式NOx計, 定電位電解 方式ガス分析計，磁気風方式 $\mathrm{O}_{2}$ 計及び赤外線吸収 方式 $\mathrm{SO}_{2}$ 計により燃焼ガス中の $\mathrm{NO}, \mathrm{NOx}, \mathrm{O}_{2}$, $\mathrm{CO}, \mathrm{CO}_{2}, \mathrm{SO}_{2}$ のガス測定を行うと共に，電子天 秤及びフイルターを用いることにより排気ガス中 のすす(PM)，ドライスート(DS)の分析を行った. 可溶性有機物質 $(\mathrm{SOF})$ を抽出するために, ジクロ ロメタン溶液を使用した.大略的に過去報告してき た手法と大きく変わらない( ${ }^{(5)}$ (7). 表 $5 に は$ 実験条 件を示す，今回は次のように，大別して 3 種類の実 験を行った。

\section{表4 実験機関要目}

\begin{tabular}{|c|c|}
\hline Engine type & $\begin{array}{l}\text { Horizontal single cylinder } 4 \\
\text { stroke diesel engine ( YANMAR } \\
\text { NF19-SK) }\end{array}$ \\
\hline Cylinder bore $\mathrm{x}$ stroke & $\Phi 110 \times 106 \mathrm{~mm}$ \\
\hline Swept volume & $1007 \mathrm{~cm}^{3}$ \\
\hline Clearance volume & $61.78 \mathrm{~cm}^{3}$ \\
\hline \begin{tabular}{|l|} 
Maximum power \\
\end{tabular} & $14.0 \mathrm{~kW} / 2400 \mathrm{rpm}$ \\
\hline Rated continuous power & $12.0 \mathrm{~kW} / 2200 \mathrm{rpm}$ \\
\hline \begin{tabular}{|l|} 
Compression ratio \\
\end{tabular} & 16.3 \\
\hline $\begin{array}{l}\text { Effective compression } \\
\text { ratio }\end{array}$ & 14.5 \\
\hline Swirl ratio & $2.20 \pm 0.1$ \\
\hline Nozzle & $\Phi 0.33 \mathrm{~mm}, 4$ hole injection \\
\hline Nozzle injection angle & $150^{\circ}$ \\
\hline \begin{tabular}{|l|} 
Injection timing \\
\end{tabular} & $19^{\circ} \pm 1$ B.TDC \\
\hline $\begin{array}{l}\text { Injection-valve opening } \\
\text { pressure }\end{array}$ & $19.6 \sim 20.1 \mathrm{Mpa}\left(200 \sim 205 \mathrm{~kg} / \mathrm{cm}^{2}\right)$ \\
\hline Cooling type & Radiator \\
\hline Weight & $192 \mathrm{~kg}$ \\
\hline
\end{tabular}

(1) C重油とWPD油を 8 対 2 混合した燃料油で機 関の負荷を $1 / 2 ， 3 / 4$ 及び $4 / 4$ と変えた場合に ついて, 燃料油非加熱状態で, 実施した。

(2) さらなる低質油を考慮し，高硫黄燃料油のた めに，添加剂DBDS([(CH3)3CS- $] 2)$ を加え， 燃料非加熱状態で，硫黄分の変化による影響 を検討した。

(3) C重油とWPDを 9 対 1 で混合した基油に水を 10，20\%(v)混合し，乳化剂を基油量に対して $0.3 \%(\mathrm{v})$ 添加した。高速度エンジンのために， 供試燃料油が $80^{\circ} \mathrm{C}$ まで加熱された。機関負荷 は75\%一定とし，機関性能及び排ガス排出特 性の試験を行った。

\section{4. 実験での性能及び排ガス試験結果}

4.1 負荷変動による結果罒7には負荷 $1 / 2$, $3 / 4 ， 4 / 4$ の場合の筒内压力線図結果を示した．高 負荷になるほど着火遅れは短くなり，最高圧力值

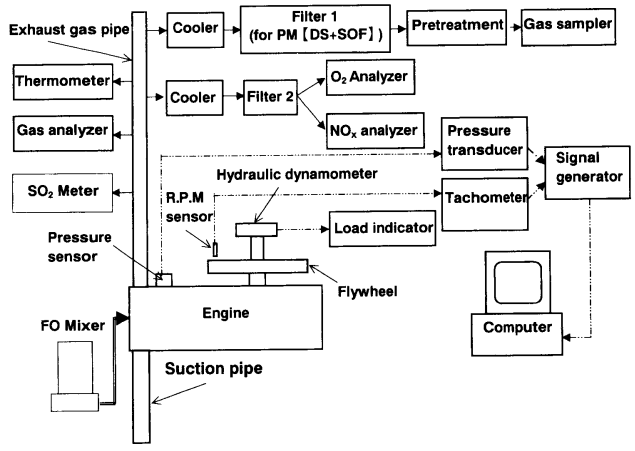

図6 実験装置概略

表 5 実験条件

\begin{tabular}{|c|c|c|c|c|c|}
\hline & & 1 & 2 & 3 & Unit \\
\hline \multirow{2}{*}{$\mathbf{I}$} & Engine load/Speed & $50 / 2200$ & $75 / 2200$ & $100 / 2200$ & $\% / r p m$ \\
\hline & WPD mixing ratio & 20 & 20 & 20 & $\%(v)$ \\
\hline \multirow{4}{*}{ II } & Engine load/Speed & $75 / 2200$ & $75 / 2200$ & $75 / 2200$ & $\% /$ rpm \\
\hline & DBDS mixing ratio & 1 & 3 & 5 & $\%(v)$ \\
\hline & Sulfur content & 1.76 & 2.33 & 2.82 & $\%(m / m)$ \\
\hline & WPD mixing ratio & 20 & 20 & 20 & $\%(v)$ \\
\hline \multirow{4}{*}{ III } & Engine load/Speed & $75 / 2200$ & $75 / 2200$ & $75 / 2200$ & $\% /$ rpm \\
\hline & WPD mixing ratio & 10 & 10 & 10 & $\%(v)$ \\
\hline & Water mixing ratio & 0 & 10 & 20 & $\%(v)$ \\
\hline & WOS21 mixing ratio & 0.3 & 0.3 & 0.3 & $\%(v)$ \\
\hline & & & & & \\
\hline DS & $\begin{array}{l}\text { load: Percentage of } C \\
\text { ixing ratio } \equiv W P D /(W P D \\
\text { mixing ratio } \equiv D B S /(W \\
\text { mixing ratio } \equiv W a t e r /(W \\
\text { mixing ratio } \equiv \text { WOS21/ }\end{array}$ & $\begin{array}{l}\text { inuous Ra } \\
\text {.OI) } \\
+ \text { C.Oil+DB } \\
+ \text { C.OII+Wa } \\
\text { PD+C.OII) }\end{array}$ & put of th & & \\
\hline
\end{tabular}


は高くなる。図8の(a)には着火遅れとともに排気 ガス温度を示した．図より高負荷になるにしたが って最高圧力值が上がり排気ガス温度も上昇する. 図8(b)，(c)には $02 ， \mathrm{COx}$ 及びNOxの排出特性を 示した。四より，高負荷になるにしたがって，燃 焼温度が上がるため, NOxの濃度が増加する。特 にNOの増加が顕著である.罒8(d)には排出微粒子 $(\mathrm{PM} \equiv \mathrm{DS}+\mathrm{SOF})$ の濃度分布を示す。負荷増加に 伴い, PMの減少は著しい, 特にSOFの低減量は 大きい.
4.2 高硫黄燃料油とWPDとの混合油本研 究に使用してきたC重油中の硫黄分を変えた場合 の，WPD混合による影響を検討した。供試燃料油 中の硫黄分を変えるために, C重油とWPDを 8 対 2 で混合した基油にDBDSを 1,3 及び5\%(v)添加する ことによって，全燃料量中の硫黄含有率を 1.76 , 2.33 及び $2.82 \%(\mathrm{~m} / \mathrm{m})$ と設定して実験を行った。図 9，10には筒内圧力線図，着火遅れ，排ガス温度及 び排ガス特性を示した。図より，硫黄分が増すほ ど，着火遅れが短くなる(8)。 $\mathrm{O}_{2}, \mathrm{COx}, \mathrm{NOx}$,

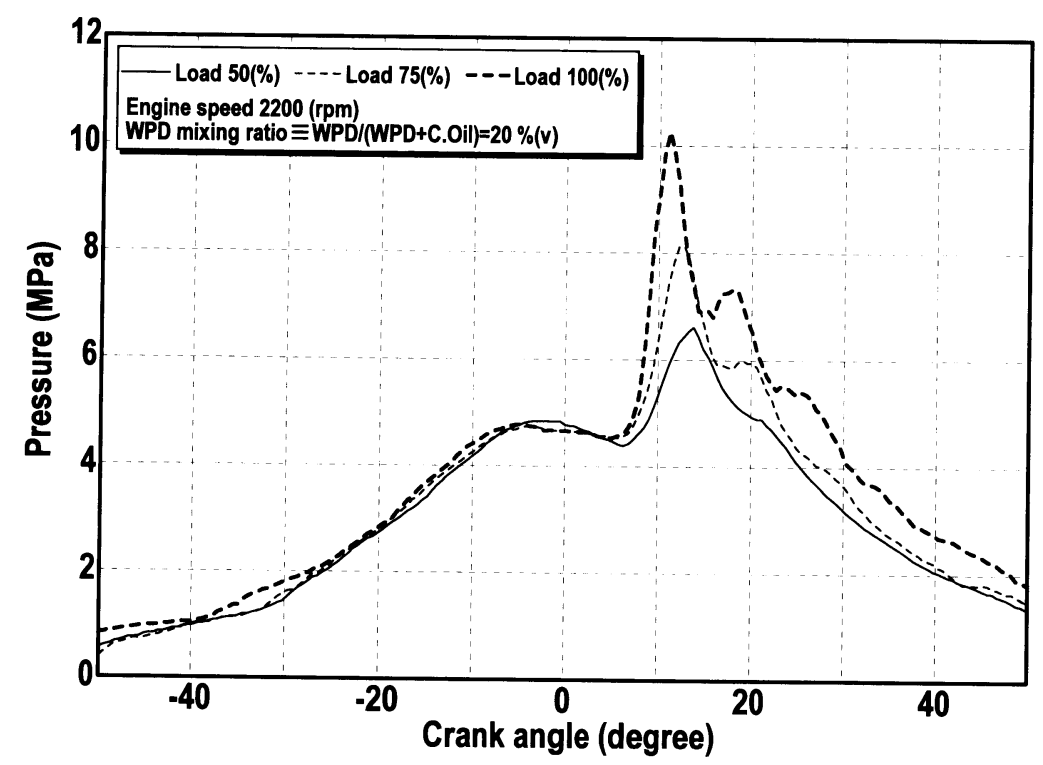

図7 圧力線図

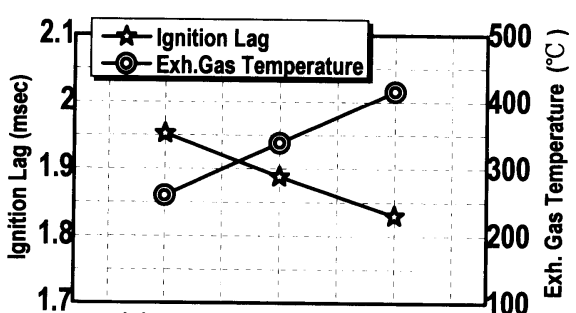

(a)

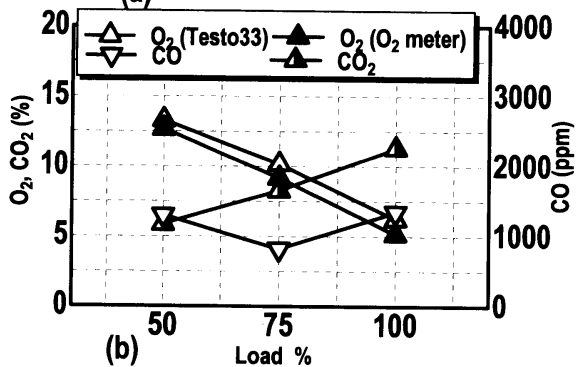

(b) $\begin{array}{cc}50 & 75 \\ \text { Load \% }\end{array}$

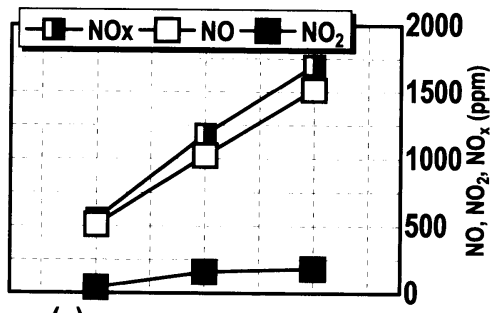

(c)

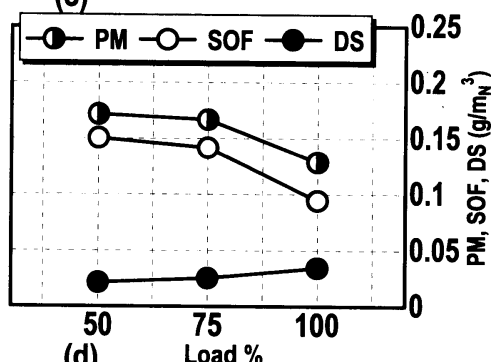

(d)

図8負荷変動による実験結果 
$\mathrm{N}_{2} \mathrm{O}$ 及びPM $(\mathrm{PM} \equiv \mathrm{DS}+\mathrm{SOF})$ の排出量分布より, $\mathrm{O}_{2}, \mathrm{COx}, \mathrm{NOx}, \mathrm{PM}$ の排出量にはS 分による大き な変化は見られないが, $\mathrm{SO}_{2}$ 量の排出量増加に伴 って，N2Oが著しく増加する。過去の報告で( ${ }^{(9)}$, $\mathrm{N}_{2} \mathrm{O}$ 值に打いて, 機関負荷の増大に伴って $\mathrm{N}_{2} \mathrm{O}$ 生 成は増し，硫黄分が 1.76 から $2.82 \%(\mathrm{~m} / \mathrm{m})$ へ増やす と $\mathrm{N}_{2} \mathrm{O}$ 排出量は約 1.5 倍増加した. $\mathrm{N}_{2} \mathrm{O}$ 生成排出には SOx生成量は大きくかかわっている.

4.3 排ガス対策としてのエマルジョン燃料 C重油とWPDを 9 対 1 で混合した基油に水を $0 ， 10$,
$20 \%(\mathrm{v})$ 混合し，乳化剂を $0.3 \%(v)$ 添加した供試燃料 油で種々実験を行った。罒11には筒内圧力線図を 示す．図12(a)で，水混合率を $10 \%(v)$ 増加すると， 動粘度が低くなり，燃料噴霧が良くなるため，着 火遅れが $1.7 \mathrm{~ms}$ に若干短くなる。図 $12(\mathrm{~b}) ，(\mathrm{c})$ は $\mathrm{O}_{2}, \mathrm{COx}, \mathrm{NOx}$ の排ガス特性を示すものである. $\mathrm{O}_{2}, \mathrm{CO}_{2}$ に対しては，水混合率増加にかかわらず に，ほぼ一定である。 NOx，SOx排出量は水添加 によって著しく減少することができた．水添加率 が増すほど，燃焼温度が下がるため，NOxは

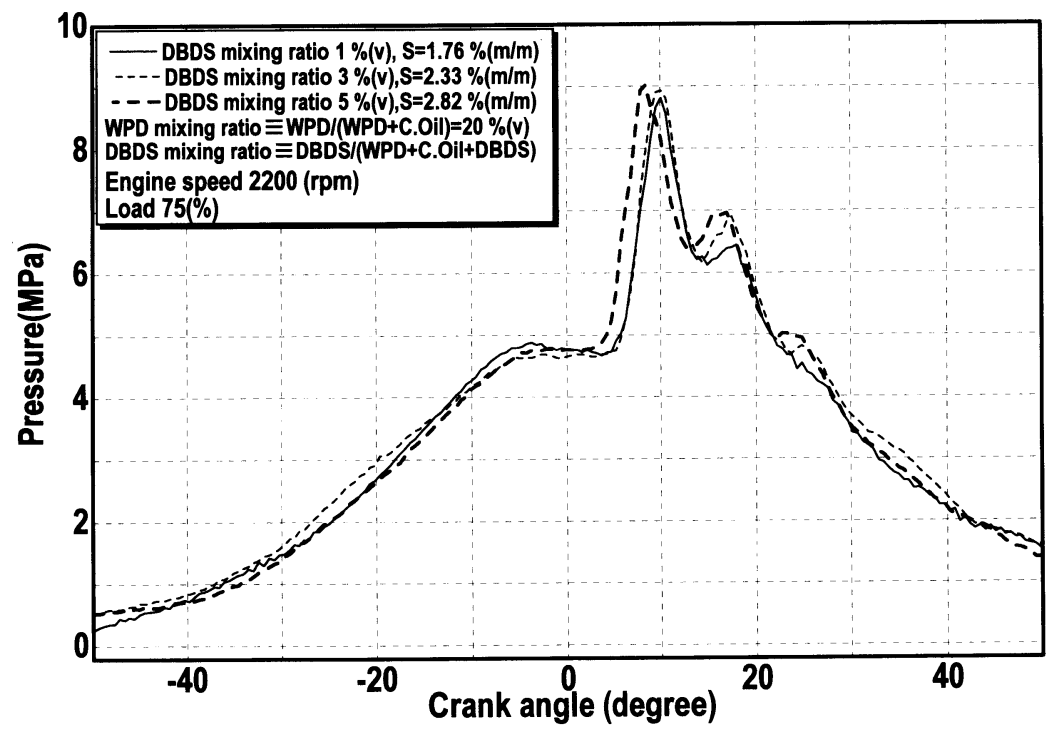

図9 圧力線図

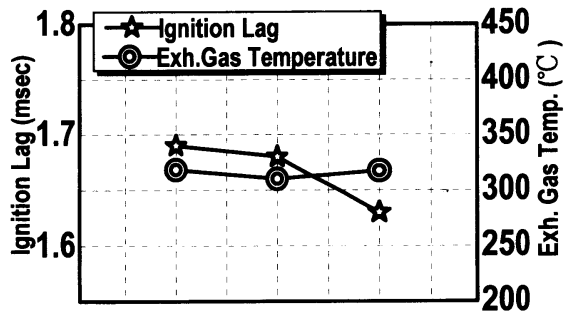

(a)

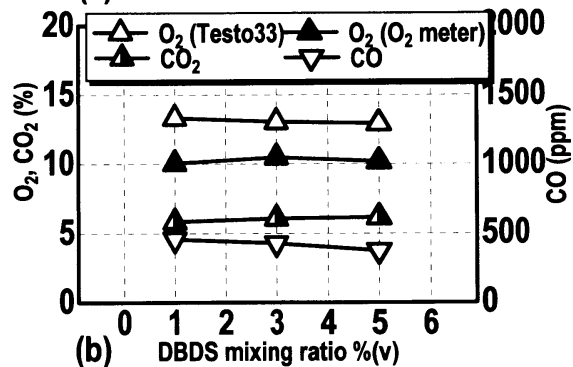

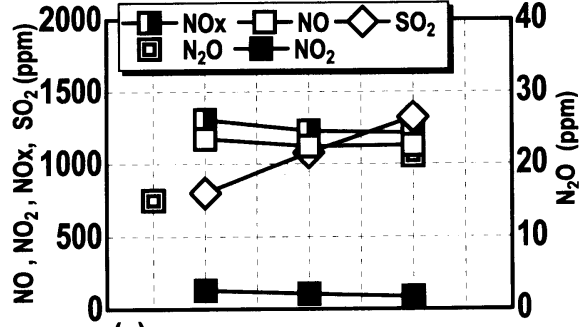

(c)

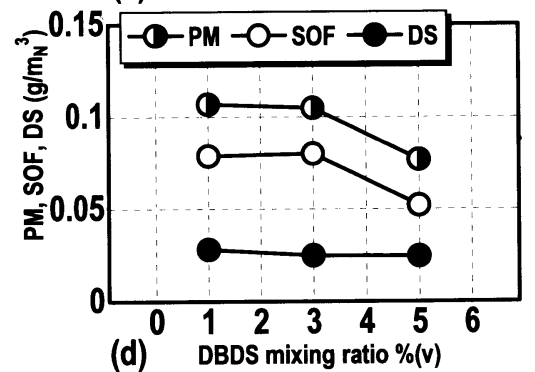

図10 硫黄分添加による実験結果 
$1180 \mathrm{ppm}$ から 497ppmまで, 59\%も急激に下がり， $\mathrm{SO}_{2}$ は 882ppmから 670ppmまで，24\%低減すること ができた。罒12(d)の微粒子結果より，水添加率増 加にかかわらずに，DSはほぼ一定であった。しか し，水化合物の増加に伴って，燃娔温度減少によ る不完全燃焼のため, SOFが増した。
5. まとめ

本研究の目的は廃棄物の再利用による舶用低質 燃料油の新設計である。これらの推進のために， 機関の負荷を変えた場合に使用できるか，また硫 黄分含有量の異なるC重油を使用した場合にどの ような機関性能が得られるか，さらに大気污染物

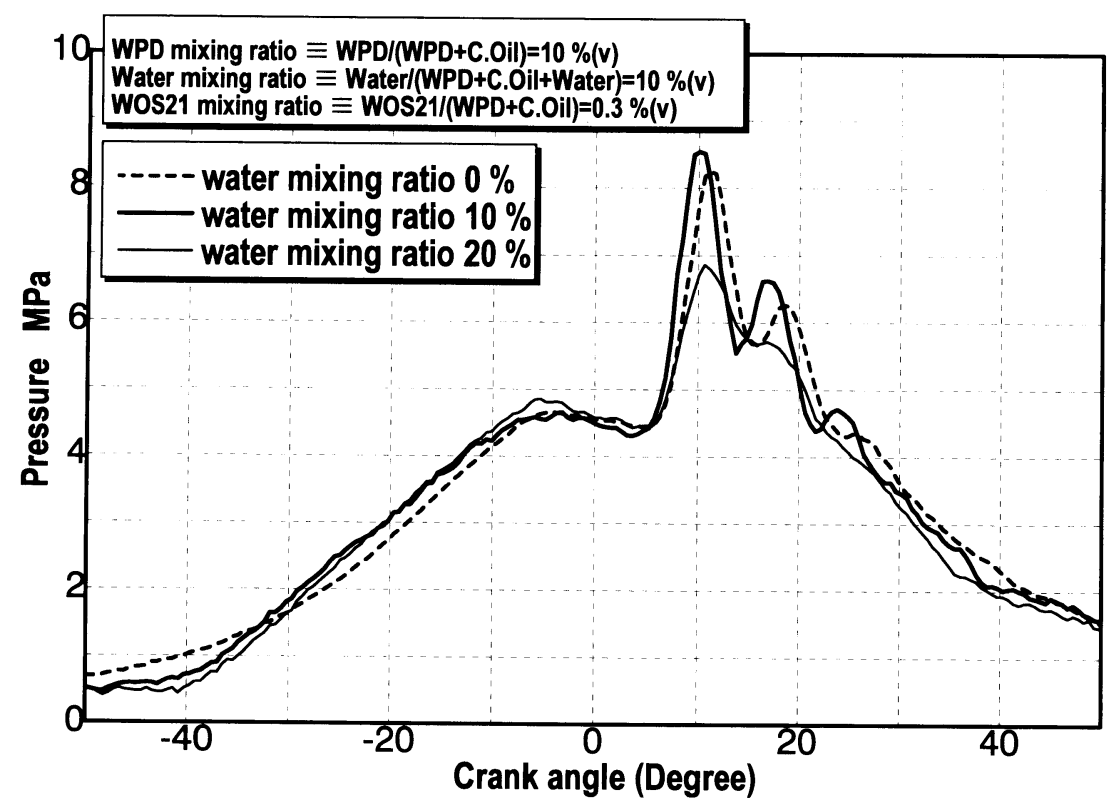

図11 圧力線図
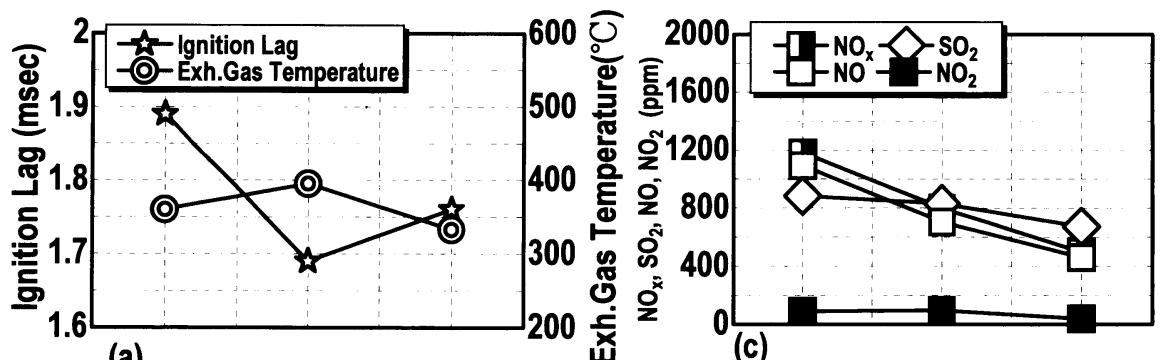

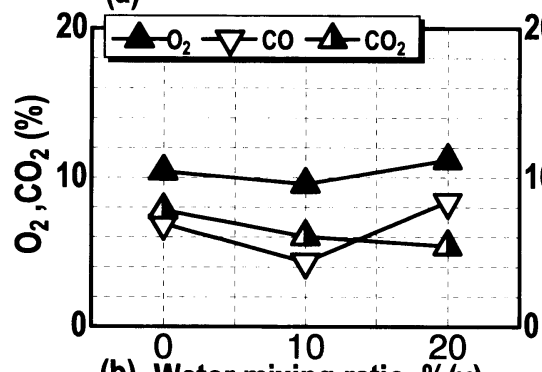

(b) Water mixing ratio \%(v)

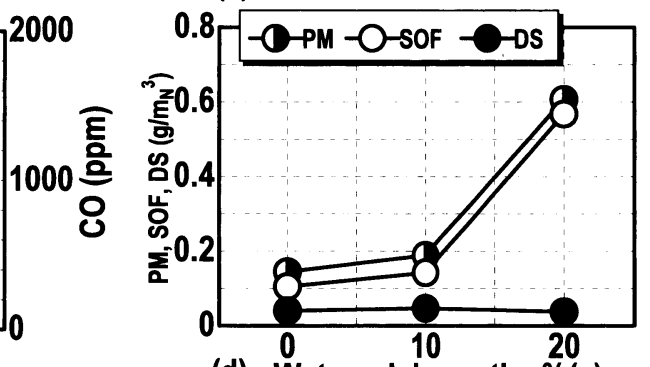

(d) Water mixing ratio \%(v)

図12 水添加による実験結果 
質低減策として, 水添加によるエマルジョン燃料 油でNOxを抑制できるかを機関性能，並びに環境 面から評価を試みた。

WPD 添加による非加熱による重質油の実用化， NOx抑制への応用的立場からディーゼル機関にて 実験した結果，大略的に次のようなことが言えた.

(1) 重質油(177cSt @ $\left.50^{\circ} \mathrm{C}\right)$ ) WPDを $10 〜 30 \%$ (v) 添加するだけで, 動粘度が $10 \sim 20 \mathrm{cSt}$ $\left(@ 50^{\circ} \mathrm{C}\right)$ に低下し, 非加熱の状態で, 小型高 速ディーゼル機関に直接使用できた。

(2) エンジン負荷の変動にかかわらずに, エンジ ン運転は問題なく, 安定であった.エンジン 負荷の増加に伴い, 着火遅れは若干短くなり, 排気ガス温度が上昇するため, 排出NOx濃 度は激増するが, 微粒子(DS, SOF) は大幅に 低減できた。特にSOFの低減は著しかった。

(3) DBDS(硫黄分) 添加率増加に伴い, 着火遅れ は若干短くなり, 排出 $\mathrm{NO}_{2}$ 濃度は若干減少し た.DSの量には変化が見られなかったが， $\mathrm{SOF}$ は若干減少した.排ガス中の $\mathrm{SO}_{2}, \mathrm{~N}_{2} \mathrm{O}$ は 増加した。

(4) C重油とWPD との混合油に水を $20 \%(v)$ まで混 合し，さらにカプセル式乳化剂で作成したエ マルジョン燃料油で, 実験した結果, 水添加 $10 \%(\mathrm{v})$ の場合, DS及びSOFの量に変化は見 られなかったが, NOx濃度は半減し, NOx 生成抑制効果は大きかった。

\section{参考文献}

(1) 岡屋裕造（日邦産業株式会社）, 「廃䢂処理 (廃プラスチック類) の為の新技術の発表」資 料, (1997年 12 月), P. 3 .

(2) 西田ら, 他7名, 日本舶用機関学会第60（平成 10 年度春季) 学術講演会講演論文集, (1998年 5月), P. 156 163 .

(3) 西田ら, 他5名, 日本機械学会講演論文集No. 984-1（1998年3月), P. 39 40.

(4) 西田ら, 他9名, 日本舶用機関学会第61回（テ クノオーシャン) (平成 10年11月25～27日秋 季) 学術講演会講演論文集, P. $13 \sim 16$.

(5) 西田ら, 他 9 名, 日本機械学会講演論文集 No. 984-2（1998年10月関西支部第256回講演会； 滋賀県立大), P. 11-5 6.

(6) 西田ら, 他 9 名, 日本舶用機関学会誌 第 34 巻 第2号 $(1999-2)$, P. 101 105 .

(7) Nishida, et al. 9, "Application of Waste Plastic Disposals to Diesel Engines”, Proceedings of 5th Asia-Pacific International Symposium on Combustion and Energy Utilization, (1999-Oct), Shanghai, China.

(8) Dan, et al. 4, "Effect of Sulfur compound in fuel oil to engine performance and exhaust emission”, Proceedings of 4th JSME-KSME Thermal Engineering Conference (vol. 3), (2000-Oct), Kobe, Japan.

(9) 西田ら, 他 18 名, エアロゾル科学·技術研究討 論会第 17 回平成 12 年 8 月 $2 \sim 4$ 日）学術講演会 講演論文集, P. $7 \sim 9$. 